\title{
Stages of Consumerism: Mass Advertising and Children's Literature in Early Twentieth-Century Sweden
}

Elina Druker

\begin{abstract}
This chapter discusses the motif of the sentient product in advertising during the I930s and I940s. The studied corpus consists of advertising that specifically targets children and adolescents but also short advertising films aimed at a wider audience. As a theoretical standpoint for my discussion, I apply Jean Baudrillard's theories about advertising and mass media and Nathalie op de Beeck's studies on the modern picture book of the interwar era and its connections to both the avant-garde and mass culture. The chapter proposes that children are to an increasing degree viewed as future members of the society but also as future consumers. The new ideas and marketing strategies expressed in the material also coincide with fundamental social changes in Swedish society resulting from modernity and new technologies. Consumption in general is described as an essential part of the modern, urban experience and the aesthetics used to describe this experience fluctuate between popular culture and experimental arts.
\end{abstract}

In the black-and-white advertising film from 1938 , The Pastille Dance (Pastilldansen) by Marabou, it is the commodities that take center stage (Figure I). In the film, the product is used to form the bodies of a female and male figure, which are constructed with round, white and black cough pastilles "Tenor" and "Figaro." The film depicts the inanimate products as dynamic and vivacious. They court each other, dance, whirl, and sing together,

How to cite this book chapter:

Druker, Elina. "Stages of Consumerism: Mass Advertising and Children's Literature in Early Twentieth-Century Sweden." In The Power of the In-Between: Intermediality as a Tool for Aesthetic Analysis and Critical Reflection, edited by Sonya Petersson, Christer Johansson, Magdalena Holdar, and Sara Callahan, 239-260. Stockholm: Stockholm University Press, 20 I 8. DOI: https://doi.org/IO.I6993/baq.j. License: CC-BY. 


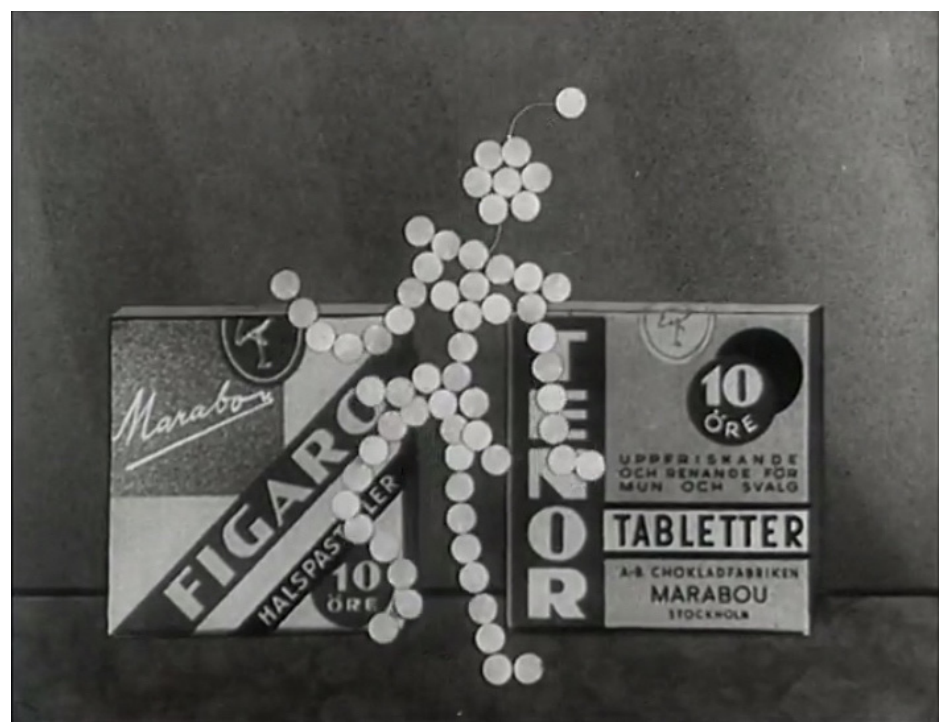

Figure 1. Advertising short film The Pastille Dance. Produced by Marabou, I93 8. Permission: Swedish Film Institute/Svenska Filminstitutet, Stockholm. License: CC-PD. Available at http:/www.filmarkivet.se/movies/ marabou-pastilldansen/.

accompanied by jazz music. The short sixty-second film then concludes with a voice-over that informs the audience of the popularity and price of the products ( $\mathrm{s}$ o öre) while the trademarks and the candy boxes are carefully presented in a final shot. ${ }^{\mathrm{I}}$

The film is one of many examples of $35 \mathrm{~mm}$ black-and-white advertising short films from the interwar era, shown in movie theatres prior to the main film, and most likely aimed at both children and adults. The motif of the anthropomorphic figures, as well as the dual target audience of the film, points at interesting connections to children's literature, where anthropomorphized characters and animals are a well-established motif from

I Advertising short film Pastilldansen by Marabou $35 \mathrm{~mm}$ (length I.37:I) black-and-white film, optic mono (1938). Available at the Film Archive of the Swedish Film Institute and National Library of Sweden, accessed April Io, 20I7, http://www.filmarkivet.se/movies/marabou-pastilldansen/. 
ancient fables to modern-day stuffed bears, toy rabbits, and dolls. However, the choice of using the products as the main characters in The Pastille Dance seems to reflect a general change of attitude in relation to how the emerging product world is demonstrated in advertising, literature, and art. This change is expressed through an increased fascination with sentient machines, mechanical bodies, and hybrids between human and machine. A similar interest is conveyed even in children's books. As Nathalie op de Beeck notes in her study of the modernist picture book, "independent-minded machines became a trendy topic in children's literature in the late I920s and I930s." ${ }^{2}$

In this chapter, I will discuss how the motif of the sentient product is used in early advertising aimed to children. I will study so-called branded picture books published for children in the I930s and I940s as well as contemporary advertising short films, with a slightly ambiguous target group. In my discussion, I will apply Jean Baudrillard's theories about advertising and mass media and Nathalie op de Beeck's research on children's literature of the interwar era, pointing at connections to both the avantgarde and mass culture. My aim is to study how different kinds of media that address both adults and children during this time period were constructed and to discuss what kind of message was conveyed to the future consumers-children.

\section{Product Placement in Picture Books}

"Look at us! We are of the best quality-KF-shoes—but we must say that it is the polish-KF's shoe polish-we have to thank for our radiant appearance."

"Now that is not quite true," said the shoe polish. "I am quite modest, if I must say, and fair's fair. Not even I could have helped you when it is so dirty outside, had you not used Gislaved's galoshes and overshoes. It is thanks to them that you can stay so

${ }^{2}$ Nathalie op de Beeck, “'The First Picture Book for Modern Children': Mary Liddell's 'Little Machinery' and the Fairy Tale of Modernity," Children's Literature 32 (2004): 79. 
clean. For the shoes', the floor's and health's sake: use Gislaved's outdoor shoes."

Per and Lisa's Christmas Kitchen, Cooperative Union (I935) ${ }^{3}$

In the opening scene of Per and Lisa's Christmas Kitchen (Per och Lisas julkök, I935) two children wake up in the middle of the night and realize that all the kitchen utensils and food products have come alive (Figure 2). The story consists of a dialogue between the two children and different kinds of products, who proudly describe their qualities and repeatedly mention their trademarks. The book is representative of publications that incorporate trademarks and products in the narratives, produced by a range of Swedish companies from the I920s on. Some of the manufacturers that can be mentioned are candy producers Mazetti and Cloetta; others are the soap company Barnängen, the manufacturer Volvo, or the pharmaceutical company Ferrosan. ${ }^{4}$ The largest producer of this kind of branded publication was, however, the Cooperative Union.

Branded publications were usually free of charge, and some of them were printed in very large editions (up to 250,000 copies) and were often written and illustrated by established authors and

3 Per och Lisas julkök (Stockholm: Kooperativa förbundet, I935). "Se på oss! Bästa kvalitet-KF-skor- men vi måste säga att det är krämenKFs skokräm—som vi har att tacka för vårt strålande yttre.” /“Det är nu inte alldeles riktigt," sa skokrämen. "Jag är blygsamheten själv och rätt skall vara rätt. Inte ens jag skulle kunna hjälpa er så smutsigt som det är ute nu, om ni inte hade använt Gislaveds galoscher och bottiner. Det är deras förtjänst att ni håller Er så fina. För skornas, golvets och hälsans skull: använd Gislaveds ytterskor."

4 See, e.g.: Bo Beskow, Sagan om den snälla Björnen (Stockholm: Barnängen, I92I); Stinas märkliga födelsedagsresa, unknown author and illustrator (Malmö: Mazetti, I928); Harry Molin, Sverige runt på 8 dagar - med Örnen: En skildring av vårt lands natur och näringsliv m.m. tillägnad skolungdomen (Stockholm: Cloetta, I945); Astrid Lindgren and Ingrid Vang Nyman, Pippi Långstrump delar ut solkulor (n.p.: Ferrosan, undated, most likely I949); Ville Volvo vinner världen och prinsessan: Modern saga, unknown author and illustrator (Göteborg: Volvo, I952). For presentation and further discussion of the genre, see Elina Druker, Eva Billow: Bilderbokskonstnär och författare (Göteborg: Makadam, 20I4), I $67-\mathrm{I} 80$. 


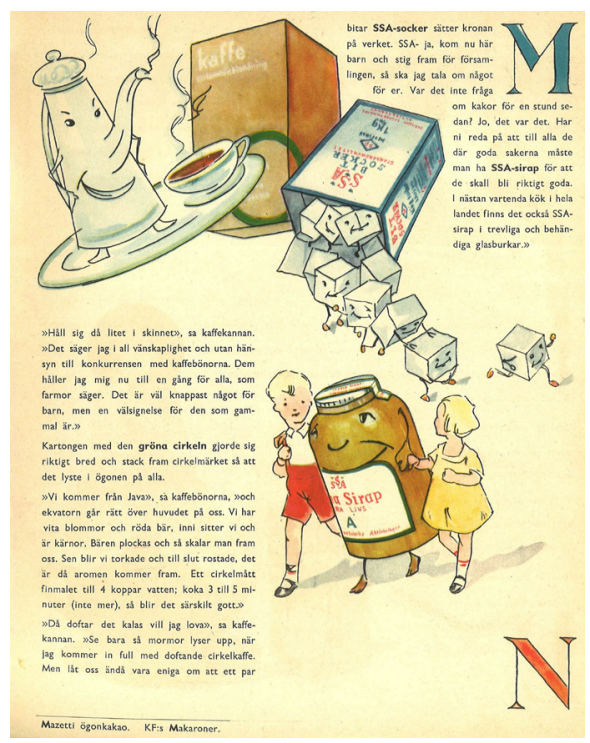

Figure 2. Anthropomorphized consumer articles in the children's picture book Per och Lisas julkök. Unknown illustrator, most likely Marie Walle. Produced by Atelier E.O., Kooperativa förbundet, I935. Reproduction: Swedish Children's Literature Institute/Svenska Barnboksinstitutet, Stockholm. License: CC-BY-NC-ND. Location of rights holder for this work has been unsuccessful after a diligent search. Copyright claims to this work are welcomed.

illustrators. ${ }^{5}$ The stories combine traditional rhymes, fairy tales, and adventure stories with advertising slogans. Product placement was implemented by including different products in the illustrations and by explicitly naming the brands in the text. Many of the books are illustrated with traditional illustration techniques, but quite often photo lithography is used and photographic reproductions of the products are included in the illustrations, creating collage-like aesthetics. ${ }^{6}$ The reader is introduced to a range of anthropomorphized consumer articles like living food items,

5 Elina Druker, "ABC for Father and Mother and Me: Representations of Children as Consumers in the Picturebook of the Interwar Period," Issues in Early Education 33:4 (2016): 33.

${ }^{6}$ Kristin Hallberg, Den svenska bilderboken och modernismens folkhem, (lic. diss., Stockholm University, I996), 5 I. 


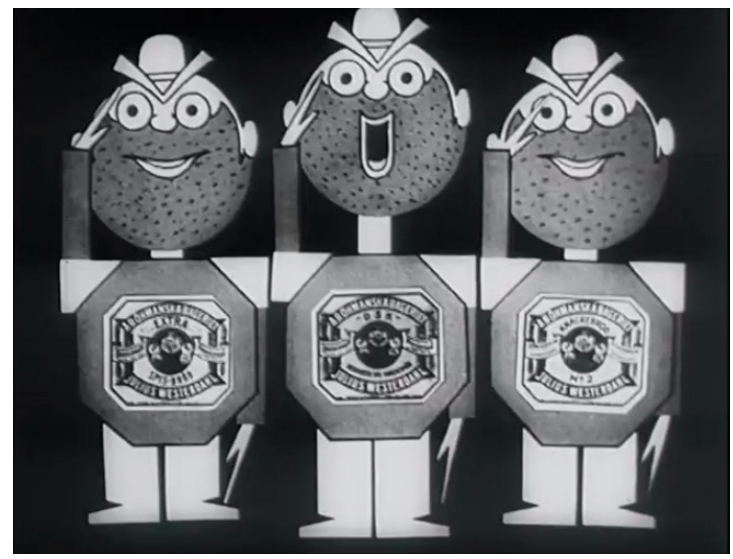

Figure 3. Advertising short film Crisp Bread Parade. Produced by Öhmans Spisbrödfabrik, I933. Permission: Swedish Film Institute/Svenska Filminstitutet, Stockholm. License: CC-PD. Available at http://www. filmarkivet.se/movies/ohmans-spisbrodsfabrik-knackebrodsparaden/.

talking light bulbs or singing coffee pots. By including the animated objects as characters in the stories, with their own characteristics, feelings and voices-and quite often as companions to the children-the advertising concept is taken beyond product placement.

\section{The Sentient Machine}

Even the advertising short film Crisp Bread Parade (Knäckebrödsparaden, I933) depicts animated and lively consumer products with human traits (Figure 3 ). In this blackand-white, drawn animated film promoting the Öhman Bread Factory, three packages of crisp bread, accompanied by brisk march music, stride forward. Their faces are shaped with round pieces of crisp bread, and their bodies formed with the bread packages. ${ }^{7}$ During the song the characters' bodies are converted

7 Advertising film “Öhmans Spisbrödfabrik - Knäckebrödsparaden” ( 9933 ). Music "March of the Björneborgers," unknown eighteenth-century composer. $35 \mathrm{~mm}$ (length I.I9:I) black-and-white film, optic mono. Available at the Film Archive of the Swedish Film Institute and National 
from boxes to human-like bodies before folding down and becoming packages again, with their brand clearly visualized. They show dynamic facial expressions and move to the music with a strong regular rhythm. The tempo matches the pace of the characters, who walk side by side in step, as if marching. With their gazes aimed toward the audience, they sing: "We are Öhman's crisp bread / from the mountains of Lapland, the hills of Småland, the plains of Skåne / you will find us." "They also call for other "victorious" crisp breads to step forward. The march music and the vocabulary, with names of Swedish landscapes and expressions like "victorious," strengthen the military feel. ${ }^{9}$

The line between the animate and inanimate is called into question in the transformations taking place in both The Pastille Dance and the Crisp Bread Parade. While the products are depicted as lively, dynamic and human-like, the actual packages and their trademarks are carefully presented to the viewer, to ensure that the merchandise and brand are easily recognizable. As Anna Dahlgren points out in her article about marketing and the visual culture of window displays, brand-name packaged goods were a relatively new medium in retail stores during the 193 os. $^{\text {I0 }}$ By repeatedly highlighting the package in various ways in different forms of advertising, the consumer was made familiar with the brand.

Library of Sweden, accessed January I6, 2017, http:/www.filmarkivet.se/ movies/ohmans-spisbrodsfabrik-knackebrodsparaden/.

8 Öhmans Spisbrödfabrik - Knäckebrödsparaden, "Vi är Öhmans knäckebröd / Bland Lapplands fjäll, Smålands kullar, Skåneslätten finner ni oss / över allting tränga fram / Ett härligt bröd, en läckerbit för frejdad stam / Stig fram du segerrika kaka / avvisa alla livets [be]kymmerfulla dar / Att sorgen liten var. Så länge som det finnes Öhmans Spisbröd kvar.”

9 Öhmans Spisbrödfabrik - Knäckebrödsparaden. Although "March of the Björneborgers” is a Finnish honorary march with lyrics by Johan Ludvig Runeberg, the mentioning of the Swedish landscapes can be seen in relation to the original text, which mentions several battlefields: "Söner av ett folk, som blött / På Narvas hed, på Polens sand, på Leipzigs slätter, Lützens kullar.”

to Anna Dahlgren, "Butiken som ansikte: Skyltning som visuell kultur" in Burkar, påsar och paket: Förpackningarnas historia i vardagens konsumtionskulturer, eds. Ulrika Torell, Roger Qvarsell, and Jenny Lee (Stockholm: Nordiska museets förlag, 20I0), I46. 
In the material studied here, the products are also associated with and represent different qualities and connotations. While the bonbons in the Pastille Dance are accompanied by lighthearted jazz music, which provides rhythmic support to their movements, the sturdy crisp breads march to Nordic military music that could be described as patriotic. In both these examples, however, the binary of the human and the machine is constantly explored through humanization of commodities and through bodily transformations. The crisp bread packages' transformations are depicted using machine-like, non-stop, rhythmic movements. Together with the text, they are associated with qualities such as vigor, strength, and resourcefulness.

Even in the branded children's books products are given different features and characteristics, depending on the item for consumption. While cleaning products and shoe polish remind the reader of the importance of hygiene and cleanliness, it is the exotic origins of items like coffee or cacao that are emphasized. The scent of Mazetti's popular Ögon-cacao is described as "tropical loveliness" and the taste of Indian Blend tea by the Cooperative Union is said to originate "from the wonderful gardens of the orient." ${ }^{\text {I }}$

Even the short film The Ideal Baking Powder (Marabou bakpulver-den idealiska burken), by Marabou (I945) emphasizes machine-like but dynamic movements (Figure 4). The black-andwhite stop motion film depicts three jars of baking powder, with arms and feet. The audience is first presented with two older products and then with a more recent version of the same brand. The new product greets his older relatives:

Hello guys! Today, I am looking so fine that you should tip your hats to me. But since your hats are so hard to get off, you don't have to bother. Instead, I would like to bow to the audience and introduce my new bayonet mount, which opens instantly. It prevents

" Per och Lisas julkök. "KF-teet India-Blend, för det riktigt ångar av Österns underbara trädgårdar” [...] “Är det inte som om alla tropikens härligheter uppenbarade sig i doften av Mazettis Ögon-kakao?” 


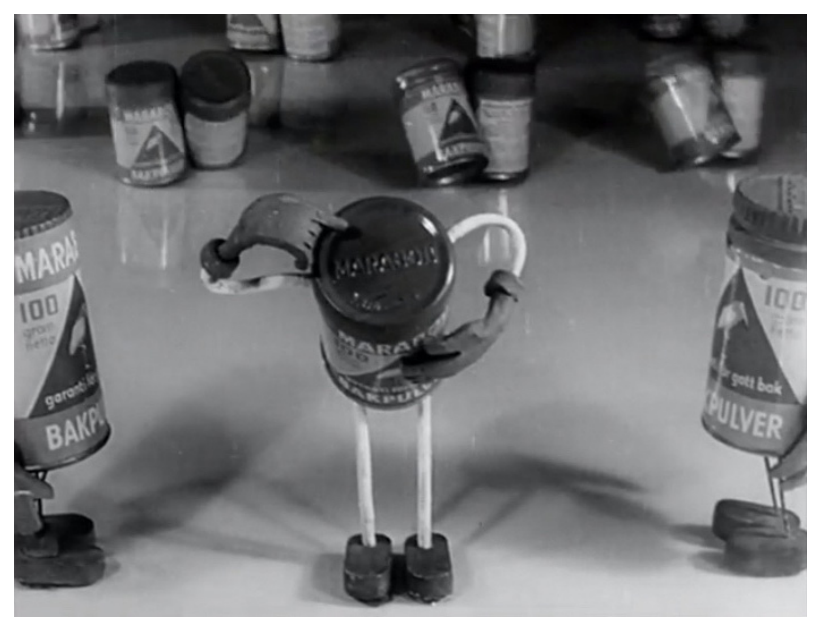

Figure 4. Advertising short film The Ideal Baking Powder. Produced by Marabou, I945. Permission: Swedish Film Institute/Svenska Filminstitutet, Stockholm. License: CC-PD. Available at http:/www.filmarkivet.se/movies/ marabou-bakpulver-den-idealiska-burken/.

spillage and protects against moisture. An ideal jar for the ideal baking powder. ${ }^{\mathrm{I} 2}$

The new jar steps forward and bows to the audience, lifting his hat/lid and presenting the new lid with its enhanced fastening mechanism. Unlike the pastilles and the crisp bread, it is not the merchandise itself_-baking powder-but its advanced packaging to which attention is called. Behind the three main characters, other jars of the same brand are depicted, engaged in a rotating, enthusiastic dance accompanied by accordion music in the French café style. They are less anthropomorphic and are depicted

I2 Advertising film “Marabou bakpulver - den idealiska burken,” ( I945), 35 mm (length I.37:I) black-and-white film, optic mono. "Hejsan grabbar! I dag är jag så fin så ni får lyfta på hatten för mig. Men ni har ju så svårt att få av den så ni slipper. I stället ska jag be att få bocka mig för publiken och presentera mitt nya lock med bajonettfattning, öppnas i en handvändning. Förhindrar allt spill, skyddar mot fukt, en idealisk burk för ett idealiskt bakpulver." Available at the Film Archive of the Swedish Film Institute and National Library of Sweden, accessed January I6, 20I7, http://www. filmarkivet.se/movies/marabou-bakpulver-den-idealiska-burken/. 
without arms and legs. In the dialogue between the characters, the juxtaposition of old and new technologies and products is emphasized, demonstrated through the meeting of the older generation and the younger, but also through the energetic movements of the dancing products and the highlighting of new technologies, represented by the novel, improved product packaging. While one of the older baking powder jars mentions that he has recently provided baking powder for a sponge cake (spilling some due to his old fashioned lid), it is noteworthy that even here, human beings are excluded entirely and the focus lies on the commodities and their interactions with each other.

An interesting characteristic in the advertising films is that the characters perform their number as actors on a stage, as if there is a live audience watching. They look directly into the camera, present themselves and the merchandise they are representing, and describe the product and its benefits. The stage-like composition can be compared to contemporary ideas about marketing and window displays. The idea of the window display as a stage was widespread during the I920s and I930s, shop windows were designed in a more theatrical way, with dramatic lighting that drew attention to the display, and products arranged in a narrative where they play their specific roles. ${ }^{13}$

This kind of use of stage-like compositions is also connected to the choice of music in the advertising films. The music is not in any way related to the products in the studied examples, but is used to convey different associations. A sense of temporariness, trendiness, and lightheartedness is created when using French café style music or jazz music, and a feeling of sturdiness and robustness is generated through march music. In his study about branding, Kevin Keller emphasizes the choice of music as a crucial part of the mental concepts or "imagery" associated with brands and brand marketing. ${ }^{\mathrm{I}}$ In the case of these early advertising films the

${ }^{13}$ See, e.g., Louise Nilsson, Färger, former, ljus: Svensk reklam och reklampsykologi, I900-I930 (PhD Diss., Uppsala: Acta Universitatis Upsaliensis, 2010), I42-I47. Dahlgren, "Butiken som ansikte," I47.

${ }^{14}$ Kevin Lane Keller, Strategic Brand Management: Building, Measuring, and Managing Brand Equity (New York City: Pearson, 2013). See also 
use of music is connected to popular culture, to dance troupes and films. Studying advertising jingles, David Huron proposes that use of music in advertising can serve the overall promotional goal in several capacities, to target a wanted demographical audience, to enhance an ad's credibility and to create memorability, to mention some of the most central objectives. ${ }^{\mathrm{I} 5}$ According to Huron, one of the most significant capacities is, however, the entertainment value of music. Advertising that is experienced as entertaining and engaging is seen as the most straightforward way of achieving the audience's attention. ${ }^{16}$ Associations with contemporary popular music, with music industry, dance troupes, and musicals in the advertising films can thus be seen as attempts to create an imagery that links the product with innovation and trendiness, but also with a sense of entertainment, even though the marketed commodities are everyday items like cough pastilles or baking products.

The interest in the modernist's fetishized thing, already introduced in avant-garde cinema and photography, is apparent in both the advertising short films and the branded picture books. They represent a mixture of the real-everyday products—and the fantastic. Aesthetically, several of the films demonstrate the influence of contemporary, experimental film. In fact, the rotating and swirling images, repetitive movements, quick cuts, and dramatic graphic forms are reminiscent of the experimental Dadaist and Surrealist cinema of the I920s, which frequently use rhythmic, machine-like effects and movements. ${ }^{17}$ Both The Pastille Dance and a following short film by the same company, Tenor \& Figaro from I939, play with the figurative and abstract, employing geometric figures in motion, organized into two-dimensional forms

Nicolai Jørgensgaard Graakjær, "The Bonding of a Band and a Brand: On Music Placement in Television Commercials from a Text Analytical Perspective," Journal of Popular Music and Society, vol. 37, issue 5 (20I4): 5I7-537.

Is David Huron, "Music in Advertising: An Analytic Paradigm," Musical Quarterly, vol. 73, no. 4 (I989): 557-574.

I6 Huron, "Music in Advertising," 562.

${ }^{17}$ See, e.g., Malcolm Turvey, The Filming of Modern Life: European Avant-garde Film of the I920s (Cambridge: MIT Press, 20II). 
and patterns. In the latter film, the product is not used to form anthropomorphic figures, but, instead, the film plays with the spatial illusionism that derives from the dynamic interplay of contrasting round forms in black and white, formed by the pastilles. This means of expression bears a resemblance with Hans Richter's abstract films from the early I920s or Oskar Fischinger's abstract colour film Optical Poem (I938), where colourful circles move rhythmically across the screen.

It appears that these early advertising films borrowed stylistic expressions and narrative techniques from both the avant-garde experimental films and the buoyant, rapidly growing mass-market entertainment. This kind of influence of the avant-garde can be seen in all fields of mass-media advertising. Inspired by both $\mathrm{fu}-$ turist and constructivist aesthetics, arrangements with consumer articles were used to form strongly stylized shapes like circles, arcs, squares, and semicircles in both posters and window displays. ${ }^{18}$ Even the functionalist ideas often emphasized repetition and machine-like aesthetics. In her description of the Cooperative Movement exhibition Without Borders in 1957, Helena Mattsson writes that using a repetitive technique of presentation of the exhibited products "was a way to de-emphasise the uniqueness of each item, and to highlight their communal quality." I9 The method of repetition of identical, mass-produced products is applied in a similar manner in the advertising short films, where the goods are used to create ornamental, rhythmic compositions. Another parallel, which is probably most obvious in The Pastille Dance, is found in the music and dance industry during the I930s and I940s, with its hugely popular dance troupes and dance films. Even here, a fascination for figures in motion is essential, with dancers, singers, or even synchronized swimmers forming rotating, rhythmic arrangements and geometric figures.

How, then, should we evaluate the transmediations and aesthetic experiments taking place in these advertising short films?

${ }^{\text {I8 }}$ Dahlgren, "Butiken som ansikte," I 50.

I9 Helena Mattsson, "Designing the Reasonable Consumer: Standardisation and Personalisation in Swedish Functionalism," in Swedish Modernism: Architecture, Consumption and the Wellfare State, eds. Helena Mattsson and Sven-Olov Wallenstein (London: Black Dog, 2010), 90. 
According to Jean Baudrillard, advertising, marketing strategies, mass media and culture, as well as the increasing proliferation of products during this era, multiplied the quantity of signs and spectacles, and created a proliferation of sign-value. Products cannot consequently merely be characterized by their use-value and exchange value, but also by their sign-value. ${ }^{20}$ The term thus describes the value given to an object because of what it communicates, rather than the material value and function derived from the use of the object. For example, the advertising film The Ideal Baking Powder not only promotes baking powder, but the product also signifies knowledge of new, modern kitchen equipment and consumer articles and, in general, a modern, up-to-date lifestyle.

At the beginning of the previous century, both the magazine and advertising industries were quick to borrow visual mannerisms from modernist art movements such as Art Nouveau or Art Deco, and later, from avant-garde movements such as Surrealism. Innovative style, speed and energy, as well as associations with new techniques and media, are an important part of the "imagery," to use Kelly's term, that is associated with the products. This means that products like baking powder or cough pastilles are promoted using mental concepts that are associated with connotations outside the product's function. The kind of stylistic imitation that is expressed in advertising could be described as a market-driven aesthetics that makes use of associations with the avant-garde-its innovation and novelty as a sign-value-and transfers these associations to the product.

\section{Designing Consumers}

Both the advertising books and the advertising short films demonstrate an interesting and dynamic meeting of commercial entertainment and artistic innovation, of oppositional and marginalized strands of art, advertisement, and culture. On one hand, repeating certain products and trademarks in different forms of advertising

${ }^{20}$ Jean Baudrillard, Selected Writings, ed. Mark Posner (Stanford: Stanford University Press, I988), 42. 
for children, the child - a future consumer-is made familiar with certain brands and trademarks. On the other hand, seen in the context of children's culture and literature, the mixed-media aesthetics applied in the commercial books, as well as the focus on machines and anthropomorphic consumer articles, means that new motifs were introduced to children. The expressions and the narrative techniques used in children's literature during this time were thus broadened.

The sentient product, both in the children's books and in the advertising films, offers an early example of media cross-over. In both these cases, objects obtain a voice and an independent agencyeven though they are at the same time depicted as mass-market commodities, produced in large quantities, and identical to other similar products. The motif with the animated, sentient consumer item reflects a general commercialization of children's daily life in the Western world that took place during the first four decades of the twentieth century, as shown by previous researchers like Viviane Zelizer or Daniel Thomas Cook. ${ }^{21}$ The development is similar in Sweden, where children were increasingly often treated as consumers in different forms of advertisement starting in the I930s. ${ }^{22}$ This coincides with a time period in Sweden where the consumer became of central concern in a wider design discourse. ${ }^{23}$ Both governmental and private actors began gradually creating consumer policies and marketing strategies in order to construct a welfare state consumer.

The idea that children's culture and literature bears ideological traces of the culture that produces them is possibly self-evident. As

${ }^{21}$ Daniel Thomas Cook, The Commodification of Childhood:The Children's Clothing Industry and the Rise of the Child Consumer (Durham: Duke University Press, 2004); Viviana A. Rotman Zelizer, Pricing the Priceless Child: The Changing Social Value of Children (New York: Basic Books, I985).

${ }^{22}$ Viveka Berggren Torell and Helene Brembeck, eds., Det konsumerande barnet: Representationer av barn och konsumtion i svensk dagsoch veckopress under I90o-talet med utgångspunkt $i$ reklamannonser (Gothenburg: Gothenburg University, 200I).

${ }^{23}$ Helena Mattsson, "Designing the 'Consumer in Infinity': The Swedish Co-operative Union's New Consumer Policy, c. I970,” in Scandinavian Design: Alternative Histories, ed. Fallan Kjetil (London: Berg, 2012 ), 67. 
Nathalie op de Beeck writes in her study of the American picture book of the interwar period, Suspended Animation: Children's Picture Books and the Fairy Tale of Modernity, "[ $\mathrm{t}]$ he picture book developed at a time when avant-garde art movements, sociopolitical climates, and changing technologies called for shifts in perceptions." ${ }^{24}$ In her study, Op de Beeck points briefly at connections between the development of the animated film and children's literature, although she doesn't discuss advertising aimed at children. She argues that while the moving images of a film and the sequential still images in a picture book "stand in different relations to time" (since the reading of a picture book is a process that can be halted, hastened, or even reversed), the early animation and picture books share similar subject matters and are strongly based on a sequentiality. ${ }^{25}$ Both animation and children's books from the interwar era also share a fascination with the mechanized body, as Op de Beeck suggests.

How should we then understand the lively, anthropomorphic products appearing in both the advertising books for children and in the short films? It is quite clear that new motifs are introduced to the child audience in the studied corpus, motifs that to some extent differ from children's literature published via traditional publishing houses. While the majority of children's literature during the interwar era still expresses strong interest in idyllic settings and fairy tales, many of the branded picture books portray new technologies through a general affirmation of speed and movement, modern means of transportation, urban environments, and technical innovations. ${ }^{26}$ The children are depicted traveling to other countries, communicating with sentient machines, flying airplanes or even space ships. The publications with embedded marketing express a general optimism and confidence in the child's capacity to cope with the urban consumer society and its new technologies and media.

${ }_{24}$ Nathalie op de Beeck, Suspended Animation: Children's Picture Books and the Fairy Tale of Modernity (Minneapolis: University of Minnesota Press, 2010), xvi.

25 Op de Beeck, Suspended Animation, I42.

${ }^{26}$ Elina Druker, "ABC for Father and Mother and Me." 
Apart from the commercial objectives expressed in the studied material, the motif of the sentient commodity can be seen as a way of addressing the urban child's increasing alienation from the means of production, instead placing the child as a consumer and an actor in a mass-market society. The fundamental changes taking place in the society meant that machines and commercially manufactured things were now becoming an increasingly important part of people's lives, including children. Personifying the machines and products can be seen as a way of establishing positive relationships between children and the changes shaped by such items and devices. Taking part in consumer information and advertisement, recognizing and relating to consumer articles, as well as responsible consumer behavior were seen as qualities that the modern child had to acquire. The branded picture books can thus be seen as a way to prepare children for future life in a consumer society.

Some of the branded books published for children also described how and where the articles were produced and include illustrations of the manufacturing plants in the stories. This is the case in, for instance, Stina's Peculiar Birthday Journey (Stinas märkliga födelsedagsresa, I928), which describes how cocoa is produced and transported to Sweden. ${ }^{27}$ The illustrations in this simple book can be described as conventional, but the concept of describing the manufacturing and transport of the product in stories for children can be seen in relation to "factual books" or "production books," which describe modern industry and technology in the young reader's modern context. ${ }^{28}$ These notions are consistent with some of the ideas about "modern" children's books that emerge during the I920s in America, Europe and Soviet Russia. An influential work in this context is Lucy Sprague Mitchell's Here and Now Story Book (I92I), in which the author applies a "here and now" methodology. This involves children learning

7 Stinas märkliga födelsedagsresa (Malmö: Mazetti, I928).

${ }_{28}$ Evgeny Steiner, "Mirror Images: On Soviet-Western Reflections in Children's Books of the I920s and I930s," in Children's Literature and the Avant-garde, eds. Elina Druker and Bettina Kümmerling-Meibauer (Amsterdam: John Benjamins Publishing Company, 20I 5), 20 I. 
about the world by studying their surrounding reality, especially modern technical things, machines, and urban life. ${ }^{29}$ Op de Beeck describes the tendency as follows: "Children were to be armed with practical understandings of the modern world so that they might become active engineers of the future, as opposed to passive victims of industry." ${ }^{\circ}$ This would mean that even advertising aimed at children could be seen as a way to offer practical understanding of the modern world and the consumer society and thus change the child audience's awareness of themselves.

In a Swedish context it is also significant that the most comprehensive and large-scale marketing strategy targeting the child audience was that of the Cooperative Union, which for several decades was a significant actor in the Swedish commercial and political landscape. The organization had a vast influence on consumer policies but also on marketing, design, and advertising, and became an important participant in the development of the Swedish welfare state. ${ }^{3 \mathrm{I}}$ Through its advertising agency Svea, the Cooperative Union developed marketing techniques that combined advertising, design, art, film, and different informational campaigns. ${ }^{32}$ Even here, the idea of repetitive marketing in different forms of advertising and media is seen as the most effective strategy.

How, then, are ideas of modernity, welfare ideology, and early consumerism connected in the studied material? According to Baudrillard, rather than promoting a specific product with the purpose of selling, advertising promotes the entire social system. In other words, advertising could be considered more as a way of signifying a way of life than an economic practice. "The fundamental, unconscious, and automatic choice of the consumer is to accept the life-style of a particular society (no longer is there a real choice: the theory of the autonomy and sovereignty of the consumer is thus refuted)," Baudrillard states in "Consumer

29 Lucy Sprague Mitchell, Here and Now Story Book: Two- to Seven-yearolds (New York: Dutton, I92I).

$3^{\circ}$ Op de Beeck, Suspended Animation, I 29.

${ }^{31}$ Mattsson, "Designing the 'Consumer in Infinity," 65.

${ }^{2}$ Mattsson, "Designing the 'Consumer in Infinity," 70. 
Society." ${ }_{33} \mathrm{He}$ argues that rather than focusing on the functional properties of the advertised goods, advertising articulates their emotional or symbolic properties, thereby unleashing an endless process of consumption that has lost its connection to exchange and only reflects a symbolic system which classifies goods into different categories. Applying Baudrillard's interpretation of the idea of the spectacle, Op de Beeck claims that the picture book of the interwar era "signals a change in reading subjects' awareness of themselves as spectators and as parts of the grand modern spectacle." 34 The advertising books and short films can thus be seen as two examples among many types of stories and images that were used in an attempt to reach the child consumer and, furthermore, with the goal of creating modern, competent consumer subjects who could function in the emerging welfare society.

\section{Conclusion}

In this chapter I have studied advertising that targets children and adolescents and demonstrates some of the wide-ranging changes taking place in Sweden during the first half of the twentieth century. Both the short advertising films and the branded publications for children are part of new commercial platforms that emerged in the beginning of the twentieth century. The occurrence of speaking, singing, and dancing anthropomorphic products in the studied corpus points at a shift during this era where children were viewed to an increasing degree as future members of the society but also as consumers. The sentient products presented in the material were used to attract both child and adult consumers and to create brand awareness among them, but they can also be seen as a way of addressing a general, increasing interaction between children, different commodities, and the consumer society.

It is apparent that already during the r930s the advertising industry is intentionally and strategically using different fields of marketing and various media, even when targeting the child

\footnotetext{
33 Baudrillard, Selected Writings, 37.

34 Op de Beeck, Suspended Animation, I62.
} 
consumer. Consumption is described as an essential part of the modern, urban experience and children are included here as both competent child consumers and as implied future (grown-up) consumers. The same products, and their brand-named packages, are presented in a range of media, from posters and window displays to short films and picture books for children. What we see is a network of media where advertising that targets children is constantly formed in connection to children's culture, media, consumerism, and art, a system of relations that swings between high arts, avant-garde, and mass culture.

When describing the quickly developing commercial market during the inter-war era in Sweden, relations between media become not only illustrative but fundamental for the mediahistorical changes taking place. The networks of influences and stimuli between different media also raises theoretical and methodological questions about the study of children's literature and culture and stresses the fruitfulness of taking a larger media-historical context in to consideration when studying media or literature targeted to children. Transmediation, in this case understood as movement of products, subject matters, and aesthetic strategies between different media, is central in the all-embracing marketing strategies applied. The depictions of the sentient products in the studied material are characterized by energetic and lively movement as well as innovative, rhythmic visual effects. The commodities convey a general sense of innovation and modernity but are also described with human-like behavior and emotions; they take center stage, not only in the advertisements, but in the modern consumer society in general.

\section{References}

Baudrillard, Jean. Selected Writings. Edited by Mark Posner. Stanford: Stanford University Press, I988.

Berggren Torell, Viveka, and Helene Brembeck, eds. Det konsumerande barnet: Representationer av barn och konsumtion i svensk dags- och veckopress under I90o-talet med utgangspunkt $i$ reklamannonser. Gothenburg: Gothenburg University, 200I. 
Beskow, Bo. Sagan om den snälla björnen. Stockholm: Barnängen, I92I.

Cook, Daniel Thomas. The Commodification of Childhood: The Children's Clothing Industry and the Rise of the Child Consumer. Durham: Duke University Press, 2004.

Dahlgren, Anna. "Butiken som ansikte: Skyltning som visuell kultur." In Burkar, påsar och paket: Förpackningarnas historia i vardagens konsumtionskulturer, edited by Ulrika Torell, Roger Qvarsell, and Jenny Lee, I43-I6I. Stockholm: Nordiska museets förlag, 20 IO.

Druker, Elina. "ABC for Father and Mother and Me: Representations of Children as Consumers in the Picturebook of the Interwar Period." Issues in Early Education 3:34 (2016): 22-35.

Druker, Elina. Eva Billow: Bilderbokskonstnär och författare. Göteborg: Makadam, 20I4.

Jørgensgaard Graakjær, Nicolai. "The Bonding of a Band and a Brand: On Music Placement in Television Commercials from a Text Analytical Perspective." Journal of Popular Music and Society, vol. 37 , issue 5 (20I4): 5I7-537.

Hallberg, Kristin. Den svenska bilderboken och modernismens folkhem. Lic. diss., Stockholm University, 1996.

Huron, David. "Music in Advertising: An Analytic Paradigm." Musical Quarterly, vol. 73, no. 4 (I989): 557-574.

Keller, Kevin Lane. Strategic Brand Management: Building, Measuring, and Managing Brand Equity. New York City: Pearson, 20I3.

Lindgren, Astrid, and Ingrid Vang Nyman. Pippi Långstrump delar ut solkulor. N.p.: Ferrosan, I949 (?).

Mattsson, Helena. "Designing the 'Consumer in Infinity': The Swedish Co-operative Union's New Consumer Policy, c. I970.” In Scandinavian Design: Alternative Histories, edited by Kjetil Fallan, 65-82. London: Berg, 20I 2.

Mattsson, Helena. "Designing the Reasonable Consumer: Standardisation and Personalisation in Swedish Functionalism." In Swedish Modernism: Architecture, Consumption and the Welfare 
State, edited by Helena Mattsson and Sven-Olov Wallenstein, 74-99. London: Black Dog, 2010.

Mitchell, Lucy Sprague. Here and Now Story Book. Two- to Sevenyear-olds. New York: Dutton, I92I.

Nilsson, Louise. Färger, former, ljus: Svensk reklam och reklampsykologi, I900-I930. PhD. Diss., Uppsala: Acta Universitatis Upsaliensis, 2010.

Molin, Harry. Sverige runt på 8 dagar - med Örnen: En skildring av vårt lands natur och näringsliv m.m. tillägnad skolungdomen. Stockholm: Cloetta, I945.

Op de Beeck, Nathalie. “'The First Picture Book for Modern Children': Mary Liddell's 'Little machinery' and the Fairy Tale of Modernity." Children's Literature 32 (2004): 4 I-83.

Op de Beeck, Nathalie. Suspended Animation: Children's Picture Books and the Fairy Tale of Modernity. Minneapolis: University of Minnesota Press, 2010.

Per och Lisas julkök. Stockholm: Kooperativa förbundet, I935.

Steiner, Evgeny. "Mirror Images: On Soviet-Western Reflections in Children's Books of the I920s and I930s." In Children's Literature and the Avant-garde, edited by Elina Druker and Bettina Kümmerling-Meibauer, I89-2I3. Amsterdam: John Benjamins Publishing Company, 201 5 .

Stinas märkliga födelsedagsresa. Malmö: Mazetti, I928.

Turvey, Malcolm. The Filming of Modern Life: European Avantgarde Film of the I920s. Cambridge: MIT Press, 20 I I.

Ville Volvo vinner världen och prinsessan: Modern saga. Göteborg: Volvo, I952.

Zelizer, Viviana A. Rotman. Pricing the Priceless Child: The Changing Social Value of Children. New York: Basic Books, 1985.

\section{Films}

Marabou bakpulver - den idealiska burken, Marabou, I945. Available at the Film Archive of the Swedish Film Institute and 
National Library of Sweden. Accessed April ıo, 20 I 7. http://www. filmarkivet.se/movies/marabou-bakpulver-den-idealiska-burken/.

Pastilldansen. Stockholm: Marabou, 1938. Available at the Film Archive of the Swedish Film Institute and National Library of Sweden. Accessed April ıo, 20 I 7. http://www.filmarkivet.se/movies/ marabou-pastilldansen/.

Öhmans Spisbrödfabrik - Knäckebrödsparaden, I933. Available at the Film Archive of the Swedish Film Institute and National Library of Sweden. Accessed April IO, 20I 7. http://www.filmarkivet. se/movies/ohmans-spisbrodsfabrik-knackebrodsparaden/. 